\section{Bright red nuclei}

Sean J. Pittock, MD, Brian G. Weinshenker, $M D$, and Claudia F. Lucchinetti, MD, Rochester, MN

A 64-year-old woman presented with a subacute onset of diplopia, dysarthria, and ataxia. MRI revealed an enhancing lesion in the right red nucleus (figure, A). She became wheelchair dependent and mute. Several possibilities were considered including a primary CNS lymphoma (PCNSL), a demyelinating lesion, and sarcoidosis. Biopsy was considered high risk and empiric steroid treatment was commenced. However, deterioration continued. A mirror image lesion developed in the left red nucleus on subsequent imaging (figure, B). Evaluation for inflammatory conditions, infections, and malignancy was negative. Spinal fluid examination (including cytology) was normal except for a lymphocytosis (77 cells). MRI 16 weeks after onset demonstrated continued progression (figure, C). Brain biopsy of the right red nucleus revealed B-cell lymphoma. PCNSL usually enhances brightly and homoge-

Address correspondence and reprint requests to Dr. Claudia Lucchinetti, Department of Neurology, Mayo Clinic, 200 First Street, SW, Rochester, MN 55905; e-mail: lucchinetti.claudia@mayo.edu

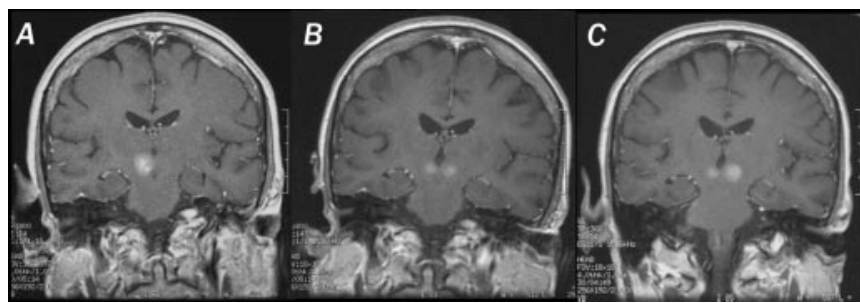

Figure. (A) Three weeks after symptom onset, coronal T1 image post contrast reveals an enhancing lesion in the right red nucleus. (B) Six weeks later, an enhancing lesion in the left red nucleus has developed. (C) Sixteen weeks after onset, bilateral enhancing lesions continue to enlarge.

neously on MRI. In immunologically competent patients, it infrequently occurs in the brainstem ( $6 \%$ of cases). ${ }^{1}$

1. Buhring U, Herrlinger U, Krings T, Thiex R, Weller M, Kuker W. MRI features of primary central nervous system lymphomas at presentation. Neurology 2001;57:393-396. 


\title{
Neurology
}

\author{
Bright red nuclei \\ Sean J. Pittock, Brian G. Weinshenker and Claudia F. Lucchinetti \\ Neurology 2004;62;619 \\ DOI 10.1212/01.WNL.0000116137.67886.F8
}

This information is current as of February 23, 2004

\section{Updated Information \& Services}

References

Citations

Subspecialty Collections

Permissions \& Licensing

Reprints including high resolution figures, can be found at: http://n.neurology.org/content/62/4/619.full

This article cites 1 articles, 1 of which you can access for free at: http://n.neurology.org/content/62/4/619.full\#ref-list-1

This article has been cited by 1 HighWire-hosted articles: http://n.neurology.org/content/62/4/619.full\#\#otherarticles

This article, along with others on similar topics, appears in the following collection(s):

MRI

http://n.neurology.org/cgi/collection/mri

Primary brain tumor

http://n.neurology.org/cgi/collection/primary_brain_tumor

Information about reproducing this article in parts (figures,tables) or in its entirety can be found online at:

http://www.neurology.org/about/about_the_journal\#permissions

Information about ordering reprints can be found online:

http://n.neurology.org/subscribers/advertise

Neurology ${ }^{\circledR}$ is the official journal of the American Academy of Neurology. Published continuously since 1951, it is now a weekly with 48 issues per year. Copyright . All rights reserved. Print ISSN: 0028-3878. Online ISSN: 1526-632X.

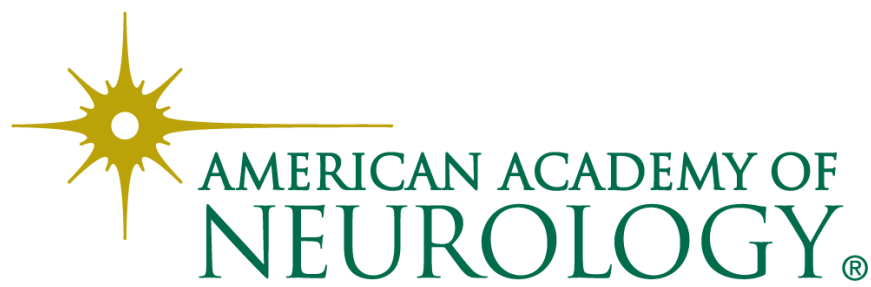

